\title{
PERAN RELEGIUSITAS DALAM MEMODERASI KEPUTUSAN INDIVIDU DALAM MEMILIH SEKOLAH DASAR ISLAM TERPADU DI KARANGANYAR
}

\author{
Apriana Nurwahyudi \& Budhi Haryanto \\ Universitas Sebelas Maret Surakarta, Indonesia \\ Email:apri_nw@yahoo.com
}

\begin{abstract}
This research to analyze variables which influence parents to make decision to send their children go to Islamic Primary School of Integrated. It aims to determine the effect of price perception, perception of quality, the image on the decision of parents to send their children go to school with religiousity as moderating variable. Collecting data using a questionnaire survey method with convenience sampling technique. The research sample of 200 respondent are individuals who want to send their children go to Islamic Primary School of Integrated, This research was carried out by taking a sample in public area such as mall, market, and kindergarten school in Karanganyar. Results SEM analysis show that religiousity as moderating influences perception of the quality of teaching, image of school, and school fee when parents sent their children go to Islamic Primary School of Integrated, because people with high religiousity will consider with influences perception of the quality of teaching, image of school, while people with lower religiousity influenced by other variable outside the variable perception of the quality of teaching, image of school dan school fee.

Keywords : Perception of price, quality of teaching, image, religiousity, decision.
\end{abstract}

\begin{abstract}
ABSTRAK
Penelitian ini untuk menguji variabel-variabel yang mempengaruhi orang tua dalam keputusan menyekolahkan anaknya di Sekolah Dasar Islam Terpadu (SDIT). Hal ini bertujuan untuk mengetahui pengaruh persepsi harga, persepsi kualitas, citra pada keputusan orang tua menyekolahkan anaknya dengan religiusitas sebagai variabel moderasi. Pengumpulan data dilakukan dengan metode survey melalui kuesioner dengan tehnik convenience sampling. Sampel penelitian sebanyak 200 responden yaitu individu yang berniat menyekolahkan anaknya ke Sekolah Dasar Islam Terpadu (SDIT). Pengambilan sampel dilakukan dipublic area yaitu di mall, supermarket, dan taman kanak-kanak di Karanganyar. Hasil uji SEM mengindikasi bahwa religiusitas memoderasi pengaruh persepsi kualitas pengajaran, persepsi citra sekolah dan biaya sekolah pada niat menyekolahkan anak di Sekolah Dasar Islam Terpadu (SDIT), karena niat menyekolahkan anak di Sekolah Dasar Islam Terpadu (SDIT) pada kelompok religiusitas tinggi mempertimbangkan persepsi kualitas pengajaran dan persepsi citra sekolah, sedangkan pada kelompok religiusitas rendah niat menyekolahkan anak di Sekolah Dasar Islam Terpadu (SDIT) diduga dipengaruhi oleh variabel lain di luar variabel persepsi kualitas pengajaran, persepsi citra sekolah dan biaya sekolah.
\end{abstract}

Kata kunci: Persepsi harga, kualitas pengajaran, citra, religiusitas, keputusan 


\section{PENDAHULUAN}

Kualitas pendidikan dasar berpengaruh pada perkembangan anak karena kualitas pendidikan yang diterima anak-anak akan berdampak pada masa depan anak (H. M. Treasury, 2004). Pendidikan dasar berpengaruh pada perkembangan intelegensi, kepribadian, perilaku sosial anak (Kaytaz, 2004), tingkat pendidikan dan status sosial di masa depan (Sylva et al., 2003). Hasil penelitian mengindikasikan bahwa pendidikan anak yang baik dapat meningkatkan kemampuan kognitif dan sosial anak (Peisner-Feinberg et al., 1999), sehingga pendidikan anak menjadi prioritas utama orang tua (Ball, 1994). Hal ini mendorong meningkatnya pertumbuhan sekolah usia dini dan pendidikan dasar di Indonesia.

Penelitian ini memfokuskan pada proses perilaku orang tua dalam menyekolahkan anaknya ke sekolah dasar berbasis pendidikan Islam. Tema ini dipilih karena pertumbuhan Sekolah Dasar Islam Terpadu (SDIT) yang sangat cepat dan merupakan salah satu fenomena yang menarik untuk dilakukan kajian. Tujuan dari penelitian ini adalah untuk mendapatkan perspektif yang lebih luas me- ngenai preferensi orang tua dalam memilih sekolah untuk anaknya khususnya di Karanganyar. Berdasarkan justifikasi penelitian awal, diketahui beberapa faktor yang mempengaruhi keputusan orang tua dalam memilih sekolah, yaitu kualitas pengajaran, biaya, citra dan religiusitas.

Dalam menentukan pendidikan dasar bagi anaknya, peran orang tua sangat dominan (Chimombo et al., 2000) terutama peran ibu (Zhang, 2011) sehingga perlu diidentifikasi faktor-faktor yang dipertimbangkan orang tua dalam memilih sekolah untuk anaknya.

Berdasarkan penelitian terdahulu menunjukan bahwa lingkungan sekolah yang memungkinkan anaknya bermain dan bersosialisasi dengan teman sebaya sebagai faktor penting (Haystead et al.,1980), tetapi penelitian (El Nokali et al., 2010) menunjukan hasil yang berlawanan karena kesempatan bermain dan bersosialisasi dengan teman sebaya bukan merupakan pertimbangan utama bagi orang tua dalam memilih sekolah untuk anaknya.

Berbagai penelitian mengindentifikasi faktor-faktor penting yang dipertimbangkan dalam memilih se- 
kolah yang terkait dengan nilai, dan kenyamana sekolah (Rose \& preferensi, pengetahuan, keyakinan dan harapan orang tua (Burges et al., Elicker, 2008). Penelitian yang lain 2009). Kualitas pengajaran adalah kualitas proses kegiatan belajar mengajar yang dilakukan oleh sekolah (Haryanto, 2009). Kualitas pengajaran menjadi tolak ukur keberhasilan kinerja akademik dalam melayani kegiatan belajar-mengajar

Faktor kenyamanan seperti jam sekolah, lokasi, transportasi dan biaya menjadi pertimbangan utama orang tua (Barbarin et al., 2006), dan menjadi pertimbangan utama orang tua berpenghasilan rendah dalam memilih sekolah untuk anaknya, dibandingkan faktor kualitas pendidikan (Early dan Buchinal, 2001).

Selain faktor kenyamanan, kualitas program pendidikan dan peningkatan prestasi anak menjadi pertimbangan utama orang tua (Pianta $e t$ $a l, .2009)$. Indikator kualitas meliputi rasio guru dan murid, pelatihan guru, kesehatan dan keselamatan murid (Rose \& Elicker, 2008), interaksi murid dengan guru dan staf sekolah, interaksi antar siswa, dan layanan staf sekolah (Barbarin et al., 2006), lingkungan sekolah dan karakter guru, keramahan guru, staf dapat dipercaya mengidentifikasi kemampuan dan kualitas akademik (Early \& Burchinal, 2001; Rose \& Elicker, 2008) serta program pendidikan (Gamble et al., 2009) menjadi pertimbangan utama orang tua dalam memilih sekolah.

Citra positif sekolah berpengaruh positif dalam perilaku orang tua dalam memilih sekolah (Kai Li dan Hung Hung, 2007). Citra sekolah dapat dibentuk dari berbagai faktor dan merupakan hasil dari proses akumulasi pengalaman, informasi yang diperoleh, kegiatan promosi sekolah, sekolah, prestasi sekolah (Nguyen dan Leblanc, 2001). Semakin banyak orang tua memiliki persepsi positif mengenai kualitas, nilai dan kepuasan, maka loyalitas pada sekolah semakin meningkat (Johnson et al., 2001). Sikap orang tua berpengaruh positif pada niat berperilaku, sehingga persepsi positif orang tua pada sekolah akan mempengaruhi perilaku dan loyalitas orang tua (Nguyen dan Leblanc, 2001).

Persepsi harga merupakan salah satu atribut penting yang mempengaruhi keputusan memilih 
sekolah (Atherton et al., 2014), dan biaya pendidikan merupakan faktor yang paling menentukan dalam keputusan pemilihan sekolah, dan berpengaruh negatif terhadap keputusan memilih sekolah (Wilkins et al,. 2013), khususnya untuk keluarga berpendapatan rendah karena pendapatan keluarga membatasi pengeluaran untuk biaya sekolah (Allen, 2004). Untuk keluarga berpendapatan tinggi, biaya sekolah tidak dibatasi oleh pendapatan keluarga, dan pemilihan sekolah lebih menekankan pada aspek kualitas (Leroux, 2015)

Religiusitas merupakan preferensi individu, emosi, keyakinan, dan tindakan yang merujuk pada agama (Stolz, 2008). Religiusitas memiliki pengaruh positif pada kelompok dan individu dalam bidang sosial dan pendidikan, karena religiusitas mengembangkan rasa kasih sayang, kejujuran, altruisme, kebahagiaan, kualitas hidup, kesehatan, dan kesehatan mental (Holdcroft, 2006). Dimensi kognitif religiusitas, pendidikan agama bukan hanya satu aspek pendidikan tetapi merupakan kekuatan yang mengikat pendidikan karena merupakan pusat proses pendidikan secara keseluruhan. Hal itu karena agama memberikan wawasan pada cara berpikir berbeda, menjadi wahana komunikasi lingkungan hidup spiritual yang diajarkan secara terbuka untuk penguatan iman dan mempengaruhi cara hidup (Sealey, 1985). Rest (1986) menemukan fakta bahwa terdapat hubungan yang bertentangan antara perilaku moral dan pertimbangan moral yang dihasilkan dari moral pendidikan, karena dampak pendidikan agama secara formal tergantung pada kualitas pendidikan dan keberhasilan program pendidikan agama dalam mempromosikan pengembangan moral merupakan interaksi lingkungan pendidikan dan karakteristik siswa. Penelitian terdahulu mengindikasikan bahwa agama merupakan indikator keberhasilan akademis (Mooney, 2005), selain itu partisipasi keagamaan dan religiusitas seseorang dapat mengurangi penyalahgunaan narkoba dan tindakan negatif yang merugikan prestasi akademis (Regnerus, 2000).

\section{LITERATUR}

Persepsi kualitas adalah persepsi pelanggan yang berkaitan dengan penilaian pribadi pelanggan ter- 
hadap keunggulan produk (Zeithaml, 1988; Aaker, 1991). Penilaian kualitas oleh konsumen seringkali berbeda karena setiap orang memiliki persepsi yang kemungkinan berbeda dalam menanggapi kualitas. Kualitas layanan merupakan penilaian masingmasing pelanggan apakah layanan yang diberikan memenuhi harapan yang ditetapkan (Czepiel, 1990), sehingga layanan disebut berkualitas jika sesuai dengan harapan pelanggan (Donnelly, 1996). Hal tersebut mengindikasikan bahwa kualitas dipersepsikan sebagai kinerja layanan yang dirasakan oleh pelanggan.

Persepsi harga adalah sesuatu yang dikeluarkan konsumen untuk memperoleh suatu produk dan konsumen tidak selalu mengingat harga aktual dari suatu produk, namun konsumen menilai harga berdasarkan mahal atau murah, (Zeithaml, 1988). Dari sudut pandang ini, harga digunakan sebagai indikator value karena harga dihubungkan dengan manfaat yang dirasakan atas suatu barang dan jasa, dan persepsi harga berkaitan dengan bagaimana informasi harga dipahami dan memberikan makna bagi konsumen (Peter dan Olson, 2005).
Persepsi biaya pendidikan merupakan salah satu atribut penting yang mempengaruhi keputusan memilih sekolah (Atherton et al., 2014), Harga seringkali digunakan sebagai indikator kualitas produk/jasa, dan berpengaruh pada ekspektasi pelanggan terhadap kemampuan produk memuaskan pelanggan. Biaya pendidikan merupakan faktor yang paling menentukan dalam keputusan pemilihan sekolah, dan berpengaruh negatif terhadap keputusan memilih sekolah (Wilkins et al,. 2013), terutama untuk keluarga berpenghasilan rendah, karena untuk keluarga berpendidikan tinggi, variabel penentu bukan harga, sehingga pada keluarga berpenaghasilan rendah, keputusan pemilihan sekolah tidak hanya berdasar pada kualitasnya, tetapi juga kewajaran harganya (Sweeney et al., 2001), dan biaya sekolah berpengaruh negatif pada perilaku memilih sekolah.

Pengertian citra adalah suatu intangible asset perusahaan yang memiliki efek positif pada penilaian pasar atas perusahaan karena citra baik mampu menimbulkan kepercayaan dan keyakinan konsumen, Dowling (2004), citra suatu merk produk ter- 
kait dengan persepsi merk produk yang lain sedangkan pengertian citra merk menurut Keller (1993) adalah persepsi merk yang tercermin dari asosiasi merk yaitu terkait dengan atribut, manfaat dan sikap terhadap merk secara keseluruhan. Dalam konteks sekolah, persepsi citra sekolah adalah kesan konsumen terhadap sekolah yang bersifat subyektif dan berbeda tiap individu.

Religiusitas adalah ciri individu yang mempunyai kecenderungan mengaplikasikan nilai keagamaan yang sesuai dengan nilai-nilai ketuhanan yang di anut (Stolz, 2008), diantaranya adalah keyakinan dan praktek kegiatan terkait dengan agama tertentu (Belmont, 1997).

Menurut Holdcroft (2006), religiusitas memiliki dua dimensi pengukuran, yang pertama adalah dimensi intelektual, yang berkaitan dengan keimanan seseorang terkait dengan agamanya, sehingga pengukuran nilai religiusitas seseorang berdasarkan pada pengetahuan keagamaannya.
MODEL PENELITIAN

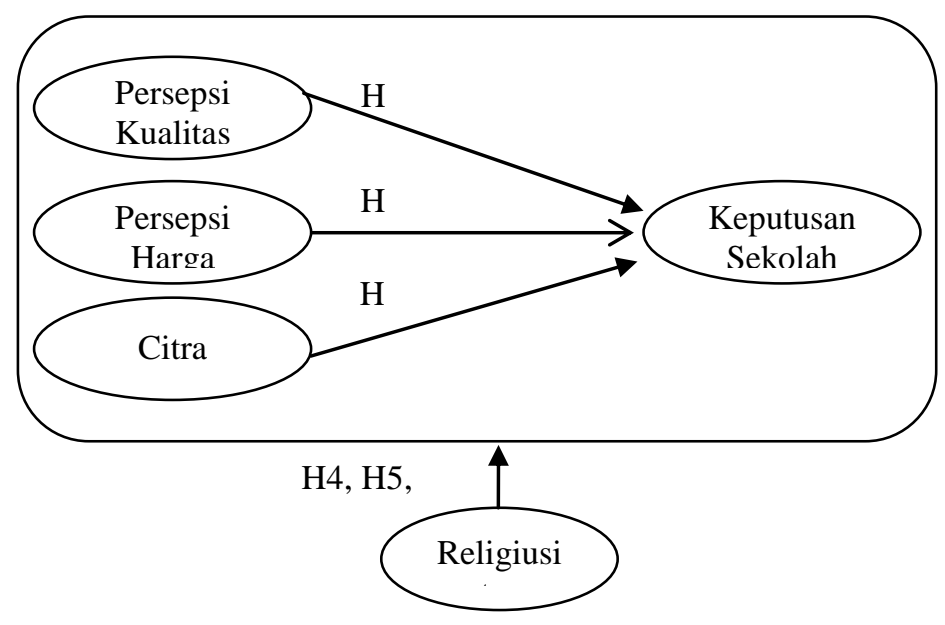

Gambar 1. Model Penelitian

Berdasarkan rumusan hipotesis dan hubungan antar variabel penelitian, maka dapat dibuat model penelitian yang menjelaskan hubungan antara, persepsi kualitas, persepsi harga, citra, keputusan memilih sekolah yang dimoderasi oleh variabel religiusitas.

Model penelitian menjelaskan pengaruh persepsi kualitas pada keputusan memilih sekolah (H1), pengaruh persepsi harga pada pada keputusan memilih sekolah (H2), pengaruh citra pada pada keputusan memilih sekolah (H3), religiusitas me-moderasi persepsi harga pada keputusan memilih sekolah (H4), religiusitas memoderasi persepsi kualitas pada keputusan memilih sekolah 
(H5) dan religiusitas memoderasi citra pada keputusan memilih sekolah (H6).

\section{METODOLOGI}

Obyek dalam penelitian ini adalah perilaku orang tua dalam menentukan Sekolah Dasar Islam Terpadu untuk anaknya di Karanganyar. Penelitian ini dilakukan di Karanganyar

Teknik pengumpulan data yang digunakan adalah metode survei dengan menggunakan kuisioner yang diberikan kepada masyarakat yang memiliki anak dan beriat menyekolahkan anaknya ke Sekolah Dasar Islam Terpadu. Populasi dalam penelitian ini adalah masyarakat yang memiliki anak dan berniat menyekolahkan ke SDIT.

Dalam penelitian ini, ukuran sampel yang akan diambil sebanyak 200 masyarakat yang memiliki anak dan berniat menyekolahkan anaknya ke SDIT sesuai syarat kecukupan sampel penelitian dengan menggunakan alat analsisis SEM. Berdasarkan hal tersebut, maka pada penelitian ini menggunakan pengambilan sampel dengan teknik convenience sampling yaitu teknik pengam- bilan sampel dengan cara kemudahan mencari responden, cara penelitiannya adalah memberikan kuisioner kepada masyarakat yang memiliki anak dan berniat menyekolahkan anaknya ke SDIT.

\section{ANALISIS STATISTIK DAN HA- SIL \\ Pembahasan pertama adalah analisis statistik deskriptif bertujuan untuk memahami profil responden. Pembahasan uji validitas dan relia- bilitas, bertujuan untuk memastikan bahwa data penelitian secara ilmiah dapat dipertanggugjawabkan kuali- tasnya. Kemudian dilanjutkan de- ngan analisis dan pembahasan kriteria goodness-of-fit model penelitian. Dan yang terakhir adalah pembahasan untuk menjelaskan hubungan antara variabel yang dihipotesiskan melalui uji Structural Equation Model (SEM).}
Analisis Data
Jumlah responden dalam penelitian ini adalah 200 orang dan memenuhi prosedur Maximum Like- lihood (ML) yaitu jumlah sampel untuk analisis SEM adalah 200 sampel. 
Apriana, Peran Religiusitas Dalam Keputusan Individu Memilih Sekolah

Tabel 1. Hasil Uji goodness-of-fit

\begin{tabular}{lccc}
\hline \multicolumn{1}{c}{ Indeks } & Cut-off & Hasil & Kesimpulan \\
\hline Chi Square & kecil & 112.28 & Fit \\
Probabilitas Chi Square (p) & $\geq 0,05$ & 0.021 & Fit \\
CMIN/DF & $\leq 2,00$ & 1.337 & Fit \\
goodness of fit index (GFI) & $\geq 0,90$ & 0.937 & Fit \\
Adjusted goodness of fit index & & & \\
(AGFI) & $\geq 0,90$ & 0.897 & Marginal \\
Comparative fit index (CFI) & $\geq 0,95$ & 0.985 & Fit \\
Tucker-Lewis Index (TLI) & $\geq 0,95$ & 0.978 & Fit \\
RMSEA & $\leq 0,06$ & 0.042 & Fit \\
IFI & $\geq 0,95$ & 0.985 & Fit \\
\hline
\end{tabular}

\section{Uji Normalitas}

Uji normalitas terdiri dari dua bagian, yaitu normalitas univariat dan yang diidentifikasi dari nilai critical ratio (c.r) skewnees dan normalitas multivariat yang diidentifikasi dari nilai critical ratio (c.r) kurtosis. Untuk jumlah sampel 200 atau lebih normalitas diidentifikasi dari critical ratio (c.r) antara -2,58 dan 2,58.

\section{Analisis Model Fit}

Tujuan dari analisis model fit adalah untuk mendapatkan kriteria goodness-of-fit model diterima dengan melakukan korelasi, dan untuk menentukan variabel/indikator yang ditambahkan korelasi maka harus berdasarkan pada teori yang mendasari (Arbuckle, 2007). Setelah dila- kukan modifikasi dengan melakukan korelasi error pada modification indices, diketahui bahwa dari beberapa kriteria fit indexs hanya Adjusted goodness of fit index (AGFI) yang marginal sedangkan lainnya memiliki kriteria fit. Karena berdasarkan uji fit hanya hanya AGFI yang marginal, maka model modifikasi dapat diindikasikan fit sehingga model diindikasikan dapat menjelaskan fenomena yang harus dijelaskan. Dan penelitian dengan teknik maximum likehood dengan jumlah sampel < 250, model dapat diindikasikan fit jika CFI, GFI, TLI, RMSEA dan IFI fit (Hu dan Bentler, 2007).

\section{Model Niat Memilih Sekolah Dasar IslamTerpadu (SDIT)}




\section{Sebelum Dimoderasi Religiu- sitas}

Setelah kriteria goodness-offit model struktural diterima, maka tahap berikutnya adalah dilakukan uji model niat memilih Sekolah Dasar Islam Terpadu (SDIT) sebelum dimoderasi religiusitas.

Uji model penelitian ini dilakukan dengan menganalisis tingkat signifikansi pengaruh variabel independen terhadap variabel dependen berdasarkan nilai CR (z-hitung) lebih besar dari atau sama dengan nilai z-tabel (z-hitung $\geq$ z-tabel). Nilai z-tabel untuk setiap tingkat signifikansi adalah: $1 \%=2,576 ; 5 \%=1,96 ;$ dan $10 \%$ $=1,645$.

Tabel 2. Hasil Uji Regresi Sebelum Moderasi

\begin{tabular}{llllrr}
\hline & & & B & \multicolumn{1}{c}{ S.E. } & \multicolumn{1}{l}{ C.R. } \\
\hline Niat & $<---$ & Kualitas & 0.165 & 0.5 & 3.306 \\
Niat & $<---$ & Citra & 0.068 & 0.04 & 1.704 \\
Niat & $<---$ & Biaya & 0.007 & 0.035 & 0.192 \\
\hline
\end{tabular}

Hasil uji model penelitian sebelum religiusitas sebagai moderator, dijelaskan sebagai berikut.

a. Pengaruh persepsi kualitas pada niat memilih Sekolah Dasar IslamTerpadu (SDIT)

Hasil uji regresi antara variabel persepsi kualitas dengan niat memilih Sekolah Dasar Islam Terpadu (SDIT) mengindikasikan bahwa persepsi kualitas berpengaruh positif dan signifikan pada niat memilih Sekolah Dasar Islam Terpadu (SDIT) $(b=0,165, \mathrm{SE}=$ 0,5 dan $\mathrm{CR}=3,306$ ), sehingga $\mathrm{H} 1$ didu-kung. Penelitian ini mengindikasikan fenomena bahwa persepsi kualitas berpengaruh positif pada niat memilih Sekolah Dasar Islam Terpadu (SDIT).

Pengaruh positif persepsi kualitas sekolah terhadap niat-niat memilih Sekolah Dasar Islam Terpadu (SDIT) sejalan dengan berbagai penelitian sebelumnya yang menyatakan bahwa kualitas program pendidikan (Early \& Burchinal, 2001; Pianta et al,. 2009; Gamble et al., 2009) dan kualitas sekolah (Rose \& Elicker, 2008, Barbarin et al., 2006) menjadi pertimbangan utama orang tua dalam memilih sekolah untuk anaknya.

\section{b. Pengaruh persepsi citra sekolah terhadap niat me- milih Sekolah Dasar Islam} Terpadu (SDIT) 
Hasil uji regresi antara variabel persepsi citra sekolah dengan niat memilih Sekolah Dasar Islam Terpadu (SDIT) mengindikasikan bahwa persepsi citra sekolah berpengaruh positif dan signifikan pada niat memilih Sekolah Dasar Islam Terpadu (SDIT) $(\mathrm{b}=$ 0,068, $\mathrm{SE}=0,04$ dan $\mathrm{CR}=$ 1.704,), sehingga $\mathrm{H} 2$ didukung.

Hasil uji regresi mengindikasikan bahwa semakin tinggi persepsi citra sekolah yang dimiliki orang tua, maka akan semakin tinggi niat orang tua untuk menyekolahkan anaknya di Sekolah Dasar Islam Terpadu (SDIT).

Hasil penelitian ini sejalan dengan literatur dan penelitian sebelumnya yang mengindikasikan bahwa per-sepsi citra sekolah berperan penting dalam keputusan pemilihan sekolah, karena jika orang tua siswa tidak memiliki pengalaman dan informasi mengenai sekolah, maka cenderung mempercayai sekolah yang sudah terkenal (Schiff-man dan Kanuk 2008). Sehingga sekolah berusaha untuk memperkuat citra sekolahnya secara positif, karena citra positif sekolah mem-bantu orang tua siswa me-ngenali sekolah, mengevaluasi kualitas sekolah, mengurangi resiko pemilihan se-kolah (Lin et al., 2007), oleh karena itu citra sekolah sangat berpengaruh terhadap kepu-tusan pemilihan sekolah (Ke-ling, 2006; Ming, 2010, Ming 2011)

\section{c. Pengaruh persepsi biaya terhadap niat memilih Sekolah Dasar Islam Terpadu (SDIT)}

Hasil uji regresi antara variabel biaya dengan niat memilih Sekolah Dasar Islam Terpadu (SDIT) mengindikasikan bahwa biaya tidak berpengaruh terhadap niat memilih Sekolah Dasar Islam Terpadu $(\mathrm{SDIT})(\mathrm{b}=0,007, \mathrm{SE}=$ 0,035 dan $\mathrm{CR}=0.192$ ), sehingga $\mathrm{H} 3$ tidak didukung.

Temuan ini tidak sejalan dengan penelitian sebelumnya yang mengindikasikan 
bahwa persepsi biaya pendidikan merupakan salah satu atribut penting yang mempengaruhi keputusan memilih sekolah (Atherton et al., 2014), dan merupakan faktor yang paling menentukan dalam keputusan pemilihan sekolah (Wilkins et al,. 2013).

Hasil ini diduga persepsi biaya sekolah tidak secara langsung mempengaruhi niat orang tua untuk menyekolahkan anaknya di Sekolah Dasar Islam Terpadu (SDIT). Perilaku orang tua dalam memilih sekolah untuk anaknya memerlukan keterlibatan tinggi sehingga persepsi biaya sekolah akan menjadi pertimbangan yang akan membentuk sikap dan berpengaruh pada niat.

Dengan demikian, dapat dikatakan bahwa hubungan antara persepsi biaya sekolah dengan niat orang tua menyekolahkan anaknya di Sekolah Dasar Islam Terpadu (SDIT) mengarah pada fenomena tidak ada hubungan
Temuan ini dapat digunakan sebagai dasar dalam merancang strategi pemasaran Sekolah Dasar Islam Terpadu (SDIT) di Karanganyar. Program yang dilakukan adalah dengan memberikan berbagai stimulus persepsi biaya yang dapat meningkatkan sikap positif orang tua terhadap Sekolah Dasar Islam Terpadu (SDIT) yang diharapkan dapat berlanjut membentuk niat positif orang tua untuk menyekolahkan anaknya di Sekolah Dasar Islam Terpadu (SDIT) (Bagozii, 1989).

\section{Model niat memilih Sekolah Dasar Islam Terpadu (SDIT) setelah di Moderasi re-ligiusitas}

Variabel moderator dalam penelitian ini adalah religiusitas dengan skala nominal berdasarkan tingkat altruismenya, sehingga uji moderasi dilakukan dengan membuat split sampel. Responden yang memiliki nilai religiusitas di atas rata-rata dikelompokan sebagai kelompok altruisme tinggi, sedangkan responden dengan nilai al- 
truisme di bawah rata-rata dikelompokan sebagai kelompok altruisme rendah. Karena variabel moderator bersifat degree, maka uji moderasi menggunakan metode uji multigroup.

Untuk menguji apakah model constrained dengan model secara signifikan dengan model unconstrained (Marsh et al., 2010).

Dari hasil uji model penelitian setelah dimoderasi religiusitas, diketahui bahwa religiusitas memoderasi model penelitian (chi square tabel $(\chi 2)>$

Tabel 3 Hasil Uji Regresi Setelah Moderasi dan Selisih Chi Square

\begin{tabular}{llc|c|c|c|c|c}
\hline & & \multicolumn{3}{c|}{ Religiusitas Tinggi } & \multicolumn{3}{c}{ Religiusitas Rendah } \\
\cline { 3 - 8 } & & B & S.E. & C.R. & b & S.E. & C.R. \\
\hline Niat $<--$ & Kualitas & 0,266 & 0,079 & 3,346 & 0,009 & 0,091 & 0,097 \\
Niat $<--$ & Citra & 0,191 & 0,081 & 2,371 & 0,101 & 0,083 & 1,209 \\
Niat $<--$ & Biaya & 0,021 & 0,045 & 0,456 & 0,07 & 0,058 & 1,212 \\
\hline
\end{tabular}

selisih chi square hitung $(\Delta \chi 2)=159,220-142,893$

$=16,327$

selisih $d f(\Delta d f)=146-136=10$

chi square tabel $(10 ; 0,05)=18,307$

chi square tabel $(\chi 2)>$ selisih chi square hitung

$(\Delta \chi 2)$

Model Constrained berbeda signifikan dengan Model Unconstrained

unconstrained berbeda secara signifikan maka digunakan uji perbandingan nilai chi square tabel $(\chi 2)$.

Dengan selisih nilai chi square hitung $(\Delta \chi 2)$. Jika chi square tabel $(\chi 2)>$ selisih chi square hitung $\left(\Delta \chi^{2}\right) \quad$ maka model constrained diindikasikan berbeda selisih chi square hitung $\left.\left(\Delta \chi^{2}\right)\right)$ sehingga model constrained secara signifikan berbeda dengan model un-constrained.

\section{a. Pengaruh persepsi kualitas pada niat memilih Sekolah Dasar Isalam terpadu}


(SDIT) di moderasi Religiusitas.

Hasil uji regresi multigroup setelah dilakukan dimoderasi religiusitas menunjukkan bahwa pada kelompok religiusitas tinggi persepsi kualitas berpengaruh positif dan signifikan pada niat orang tua menyekolahkan anaknya di Sekolah Dasar Islam Terpadu $(\mathrm{SDIT}) \quad(\mathrm{b}=0,266, \quad \mathrm{SE}=$ 0,079, dan C.R = 3,346).

Temuan penelitian ini mengindikasikan bahwa pada kelompok religiusitas tinggi, terdapat fenomena yang cenderung bahwa persepsi kualitas berpengaruh positif pada niat orang tua menyekolahkan anaknya di Sekolah Dasar Islam Terpadu (SDIT).

Sedangkan pada kelompok religiusitas rendah diperoleh fakta bahwa persepsi kualitas tidak berpengaruh pada niat orang tua menyekolahkan anaknya di Sekolah DasarIslam Terpadu (SDIT) $(\mathrm{b}=0,009, \mathrm{SE}=0,091 \mathrm{dan}$ C. $R=0,097$, ,). Temuan penelitian ini mengindikasikan bahwa pada kelompok religiusitas rendah, persepsi kualitas pada pada niat orang tua menyekolahkan anaknya di Sekolah Dasar Islam Terpadu (SDIT) cenderung mengarah pada fenomena tidak ada hubungan.

Dari hasil uji regresi multigroup pada kelompok religiusitas tinggi dan rendah diperoleh fakta bahwa terdapat perbedaan pengaruh persepsi kualitas niat orang tua menyekolahkan anaknya di Sekolah Dasar Islam Terpadu (SDIT). Hal tersebut didukung fakta bahwa chi square tabel $\left(\chi^{2}\right)>$ selisih chi square hitung $(\Delta \chi 2)$, sehingga pengaruh persepsi kualitas terhadap niat orang tua menyekolahkan anaknya di Sekolah Dasar Islam Terpadu (SDIT) pada kelompok religiusitas tinggi dan rendah diindikasikan berbeda secara signifikan, atau dengan kata lain bahwa religiusitas memoderasi pengaruh persepsi kualitas terhadap terhadap niat orang tua menyekolahkan 
anaknya di Sekolah Dasar Islam Terpadu (SDIT) pada kelompok religiusitas tinggi dan rendah. Hasil uji moderasi tersebut menunjukkan bahwa H4 didukung.

\section{b. Pengaruh persepsi citra} pada niat orang tua menyekolahkan anaknya di Sekolah Dasar Islam Terpadu (SDIT)

Hasil uji regresi multigroup setelah dilakukan dimoderasi religiusitas menunjukkan bahwa pada kelompok religiusitas tinggi, persepsi citra berpengaruh positif dan signifikan pada niat orang tua menyekolahkan anaknya di Sekolah Dasar Islam Terpadu (SDIT) $(b=0,191, \mathrm{SE}=0,081$ dan C.R $=2,371$, ). Temuan penelitian ini mengindikasikan bahwa pada kelompok religiusitas tinggi, pengaruh persepsi citra pada niat orang tua menyekolahkan anaknya di Sekolah Dasar Islam Terpadu (SDIT) cenderung mengarah pada fenomena berpengaruh secara positif dan konsisten dengan penelitian sebelumnya.

Sedangkan pada kelompok religiusitas rendah diperoleh fakta bahwa persepsi citra berpengaruh tidak berpengaruh pada niat orang tua menyekolahkan anaknya di Sekolah Dasar Islam Terpadu (SDIT) $(\beta=0,101$, C.R $=$ $0,083$ dan $\mathrm{SE}=1,209)$. Hasil uji tersebut mengindikasikan bahwa pada kelompok altruisme rendah, pengaruh persepsi citra pada niat orang tua menyekolahkan anaknya di Sekolah Dasar Islam Terpadu (SDIT) cenderung mengarah pada fenomena tidak berpengaruh.

Dari hasil uji regresi multigroup pada kelompok religiusitas tinggi dan rendah diperoleh fakta bahwa terdapat perbedaan pengaruh persepsi citra pada niat orang tua menyekolahkan anaknya di Sekolah Dasar Islam Terpadu (SDIT). Hal tersebut didukung fakta bahwa chi square tabel $(\chi 2)>$ selisih chi square hitung $(\Delta \chi 2)$, sehingga pengaruh 
persepsi citra pada pada niat orang tua menyekolahkan anaknya di Sekolah Dasar Islam Terpadu (SDIT) pada kelompok altruisme tinggi dan rendah diindi-kasikan berbeda secara sig-nifikan, atau dengan kata lain bahwa religiusitas memoderasi pengaruh persepsi citra pada pada niat orang tua menyekolahkan anaknya di Sekolah Dasar Islam Terpadu (SDIT) pada kelompok religiusitas tinggi dan rendah. Hasil uji moderasi tersebut menunjukkan bahwa H5 didukung.

\section{c. Pengaruh biaya sekolah} terhadap niat orang tua menyekolahkan anaknya di Sekolah Dasar Islam Terpadu (SDIT)

Hasil uji regresi multigroup setelah dilakukan dimoderasi religiusitas menunjukkan bahwa pada kelompok religiusitas tinggi, biaya sekolah tidak berpengaruh terhadap niat orang tua menyekolahkan anaknya di Sekolah Dasar Islam Terpadu (SDIT) $(b=0,021, S E=0,045, C \cdot R=$ 0,456,). Pada kelompok religiusitas rendah biaya sekolah juga tidak berpengaruh terhadap niat orang tua menyekolahkan anaknya di Sekolah Dasar Islam Terpadu (SDIT) $(b=0,07, C . R=0,058$ dan $\mathrm{SE}=1,212)$.

Temuan penelitian ini mengindikasikan bahwa pada kelompok religiusitas tinggi dan rendah, pengaruh biaya sekolah terhadap niat orang tua menyekolahkan anaknya di Sekolah Dasar Islam Terpadu (SDIT) cenderung mengarah pada fenomena tidak berpengaruh.

Dari hasil uji regresi multigroup pada kelompok religiusitas tinggi dan rendah diperoleh fakta bahwa terdapat perbedaan pengaruh biaya sekolah terhadap terhadap niat orang tua menyekolahkan anaknya di Sekolah Dasar Islam Terpadu (SDIT). Hal tersebut didukung fakta bahwa chi square tabel $(\chi 2)>$ selisih chi square hitung $\left(\Delta \chi^{2}\right)$, sehingga pengaruh biaya seko- 
lah terhadap pada niat orang tua menyekolahkan anaknya di Sekolah Dasar Islam Terpadu (SDIT) pada kelompok religiusitas tinggi dan rendah diindikasikan berbeda secara signifikan, atau dengan kata lain bahwa religiusitas memoderasi pengaruh biaya sekolah terhadap niat orang tua menyekolahkan anaknya di Sekolah Dasar Islam Terpadu (SDIT). Hasil uji moderasi tersebut menunjukkan bahwa H6 didukung.

\section{SIMPULAN}

Berdasarkan hasil uji model penelitian dan pembahasan, maka simpulan penelitian ini dapat jelaskan sebagai berikut:

Sebelum niat menyekolahkan anaknya di Sekolah Dasar Islam Terpadu (SDIT) dibedakan menurut tingkat religiusitasnya, menyekolahkan anaknya di SEkolah Dasar Islam Terpadu (SDIT) dipengaruhi oleh persepsi kualitas pengajaran dan persepsi citra sekolah, tetapi tidak dipengaruhi oleh biaya sekolah.

Tetapi setelah niat menyekolahkan anaknya di Sekolah Dasar
Islam Terpadu (SDIT) dibedakan menurut tingkat religiusitasnya, maka niat menyekolahkan anaknya di Sekolah Dasar Islam Terpadu (SDIT) pada kelompok religiusitas tinggi dipengaruhi oleh persepsi kualitas pengajaran dan persepsi citra sekolah dan tidak dipengaruhi oleh biaya sekolah. Pada kelompok religiusitas rendah niat menyekolahkan anaknya di Sekolah Dasar Islam Terpadu (SDIT) tidak dipengaruhi oleh persepsi kualitas pengajaran, persepsi citra sekolah, dan biaya sekolah.

Hasil uji multigroup tersebut mengindikasikan bahwa religiusitas memoderasi pengaruh persepsi kualitas pengajaran, persepsi citra sekolah dan biaya sekolah pada niat menyekolahkan anaknya di Sekolah Dasar Islam Terpadu (SDIT), karena niat menyekolahkan anaknya di Sekolah Dasar Islam Terpadu (SDIT) pada kelompok religiusitas tinggi mempertimbangkan persepsi kualitas pengajaran dan persepsi citra sekolah, sedangkan pada kelompok religiusitas rendah niat menyekolahkan anaknya di Sekolah Dasar Islam Terpadu (SDIT) diduga dipengaruhi oleh variabel lain di luar variabel persepsi 
kualitas pengajaran, persepsi citra sekolah dan biaya sekolah.

\section{Implikasi Penelitian}

\section{Implikasi Teoritis}

Implikasi teoritis pada penelitian ini adalah, penelitian ini fokus pada religiusitas tinggi dan rendah dalam konteks niat menyekolahkan anaknya di Sekolah Dasar Islam Terpadu (SDIT) yang pada penelitian terdahulu belum terjelaskan. Item pertanyaan yang digunakan pada penelitian ini sesuai dengan konteks Indonesia. Implikasi teori yang terakhir pada penelitian ini mengindikasikan bahwa religiusitas terbukti memoderasi perilaku donor darah.

\section{Implikasi Studi ke Depan}

Model penelitian ini dapat digunakan untuk penelitian selanjutnya dalam konteks niat menyekolahkan anaknya di Sekolah Dasar Islam Terpadu (SDIT) di luar Karanganyar maupun digunakan untuk penelitian di luar konteks niat menyekolahkan anaknya di Sekolah Dasar Islam Terpadu (SDIT) sehingga dapat mening- katkan generalisasi konsep yang lebih luas.

\section{Implikasi Praktis}

Hasil penelitian ini dapat digunakan sebagai dasar bagi Sekolah Dasar Islam Terpadu (SDIT) dalam menyusun strategi pemasaran untuk meningkatkan jumlah siswa dengan mendesain stimulus-stimulus yang dapat meningkatkan niat orang tua menyekolahkan anaknya di Sekolah Dasar Islam Terpadu (SDIT). Stimulus-stimulus yang dimaksud adalah yang terkait dengan meningkatkan niat orang tua menyekolahkan anaknya di Sekolah Dasar Islam Terpadu (SDIT) yaitu dengan mempertimbangkan perbedaan tingkat religiusitas orang tua.

\section{Keterbatasan Penelitian}

Model penelitian ini menggunakan masyarakat Karanganyar sebagai obyek penelitian, sehingga berdampak pada keterbatasan generalisasi penelitian dan aplikasinya hanya dapat diterapkan di Karanganyar. Berkaitan dengan keterbatasan tersebut, maka disarankan model pe- 
nelitian ini dapat diaplikasikan pada lokasi dan obyek yang berbeda sehingga dapat meningkatkan generalisasi konsep.

\section{DAFTAR PUSTAKA}

Aaker, David. 1991. Managing Brand Equity. Capitalizing on the Value of a Brand Name. Free Press: New York.

Ajzen, Icek. (2005). Attitudes, Personality and Behavior 2e. McGraw-Hill International.

Allen, Rebecca. 2014. School performance and parental choice of school: secondary data analysis. Centre for Understanding Behaviour Change. ISBN: 978-1-78105-295-2.

Arbuckle, 2007 Arbuckle, JL. 2007. Amos 16.0 User's Guide US : Amos Development Corporstion

Atherton, G., Jones, S., Hall, A. 2014. Does Cost Matter? Students understanding of the higher education finance system and how cost affects their decisions. National Education Opportunities Network.

Bagozii, R. P., Baumgartner, J., Yi, Y. 1989. An Investigation into the Role of Intentions as Mediators of AttitudeBehavior Relationship. Journal of Economic Psychology, 10: 35-62.

BALL, C. 1994. Start Right: the importance of early learning
(London, Royal Society for the Encouragement of Arts, Manufactures and Commerce).

Barbarin, O. A., McCandies, T., Early, D., Clifford, R. M., Bryant, D., Burchinal, M.,. 2006. Quality of Prekindergarten: What families are looking for in public sponsored programs. Early Education and Development, 17(4), 619-642.

Bergan, A., \& McConatha, J. T. 2000. Religiosity and life satisfaction. Activities, Adaptation and Aging, 24(3), 23-34.

Burges, Simon., 2009. Parental choice of primary school in England: what types of school do different types of family really have available to them? Journal Policy Studies, Vol. 32, No. 5, pp. 531-547.

Czepiel, J., 1990. Managing Relationships with Customers: A Differentiation Philosophy of Marketing. In D. E. Bowen, R. B. Chase, and T. G. Cummings, eds. Service Management Effectiveness. San Francsco: Jossey-Bass, 299323.

Dowling, G.R. 2004. Corporate Reputations: Should You Compete on Yours?. California Management Review, Vol. 46 No. 3, Spring 2004; (pp. 19-36.

Early, D. M., \& Burchinal, M. R. 2001. Early childhood care: relations with family charac- 
teristics and preferred care characteristics. Early Childhood Research Quarterly, 16 (4), 475-497.

El Nokali, N. E., Bachman, H. J., \& Votruba-Drzal, E. (2010). Parent involvement and children's academic and social development in elementary school. Child development, 81(3),988-1005.

Gamble, Susan., Parenting Education Programs: Recruiting and Retaining Low-income Parents and Family Caregivers. West Virginia University Extension Journal. Ncsu.edu/ ffci.

Glock, C. Y., \& Stark, R. 1965. Religion and society in tension. San Francisco: Rand McNally.

H.M. Treasury. 2004. Choice for parents, the best start for children: a ten year strategy for childcare. London: www.hm-treasury.gov.uk.

Haryanto, Budhi. 2009. Efikasi Diri, Kualitas Pengajaran, Sikap Positif, dan Kinerja Akademis Mahasiswa, Jurnal Ilmu Pendidikan. Oktober 2009 (ISSN 0215-9643).

Haystead, J.,. 1980. Pre-school Education and Care. Scottish Council For Research In Education.ISBN 10: 09011167 34/ISBN 13: 9780901116734.

Hasting, Justine S.; Richard Van Weel-den and Jeffrey Weinstein. 2007. Preferences, Infor- mation, and Parental Choice Behavior in Public School Choice. National Bureau of Economic Research Working Paper Series, No. 12995.

Holdcroft, Barbara. 2006. What Is Religiosity?. Journal of Inquiry and Practice, v10 n1 p89103 Sep 2006.

Hooper, D., Coughlan, J., Mullen, M. R. 2008. Structural Equation Modelling: Guidelines for Determining Model Fit. Electronic Journal of Business Research Methods Volume, 6( Issue 1): 53-60

Hu, L., Bentler, P. M. 1998. Fit Indices in Covariance Structure Modeling: Sensitivity to Under-parameterized Model Misspecification. Psychological Methods, 3(4): 525-453.

Jacob, B. A. and L. Lefgren. 2007. "What Do Parents Value in Education? An Empirical Investigation of Parents' Revealed Preferences for Teachers." Quarterly Journal of Economics, 122(4), pp. 160337.

Janiszewski, C. and Cunha, M. 2004. The Influence of Price Discount Framing on the Evaluation of a Product Bundle. Journal of Consumer Research, Vol. 30, No. 4 (March 2004), pp. 534-546.

Johansen, A. S., Leibowitz, A., \& Waite, L. J. (1996). The importance of childcare characterisics to choice of care. 
Journal of Marriage and Family, 58, 759-772.

Johnson, M. D., A. Gustafsson, T.W. Andreassen, L. Lervik and J. Cha. 2001. The Evolution and Future of National Customer Satisfaction Indices. Journal of Economic Psychology, 22 (2): 217-245.

Kai Li, Chung. And Hung Hung, Chia. 2007. Marketing tactics and parents loyalty: the mediating role of school image. Journal of Educational Administration. Vol. 47 No.4, 2009 pp.477-489.

Kano, Y., \& Azuma Y. (2003). Use of SEM programs to precisely measure scale reliability. In $\mathrm{H}$. Yanai et al. (Eds.), New developments in psychometrics (pp. 141-148). Tokyo: Springer Verlag.

Kaytaz, M. 2004. A Cost Benefit Analysis of Preschool Education in Turkey. Mother Child Education Foundation, 1-26.

Keling, S.B.A. 2006. Institutional factors attracting students to Malaysian institutions of higher learning international Review Of Business Research Papers, 2(1), 46-64

Kunkel, J.H. and Berry, L.L. 1968. A Behavioral Conception of Retail Image. Journal of Marketing, 32, 21-27.

Kysel, F., Varlaam, A., Stoll, L., Sammons, P. 1983. The Child at School: A New Behaviour Schedule. Inner London Edu- cation Authority, Research and Statistics Branch, London; (Internal Report RS 907/83.).

Leroux, Gabrielle. Choosing to succeed: Do parents pick the right schools?. Social Market Foundation.

Lin, H.F Lin (2007) Knowledge sharing and firm innovation capability: an empirical study international Journal of Manpower, 28 (2007), pp 315332.

Ming, J.S.K. 2010. Institutional Factors Influencing Students College Choice Decision in Malaysia: A Conceptual Framework. International Journal of Business and Social Science, Vol. 1 No. 3; December 2010.

Ming, J.S.K. 2011. A Model of Higher Education Institutions Choice in Malaysia: A Conceptual Approach. International Conference on Business and Economics Research, vol.1 (2011).

Mooney, M. 2010. Religion, college grades, and satsfacton among students at elite colleges and universites. Sociology of Religion, 71(2), 197-215.

Nguyen, N. and Leblanc, G. 2001, "Corporate image and corporate reputation in customers' retention decisions in services", Journal of Retailing and Consumer Services, Vol. 8 No. 4, pp. 227-36. 
Olivares, A. M., Forero, C. G. 2010. Goodness-of-Fit Testing. International Encyclopedia of Education, 7: 190-196.

Peisner-Feinberg, E. S., Burchinal, M. R., Clifford, R.M., Culkin, M. L., Yazejian, N., Zelazo, J., Howes, C., Byler, P., Kagan, S. L. and Rustici, J. (1999) The children of the Cost, Quality, and Outcomes Study Go To School: Technical Report. Chapel Hill: University of North Carolina at Chapel Hill, Frank Porter Graham Child Development Centre.

Peter, J.P., and Olson, J.C. 2005. Consumer Behaviour and Marketing Strategy. New York: Mc. Graw Hill.

Pianta, R., Barnett, W. S., Burchinal, M., \& Thornburg, K. R. (2009). The effects of preschool education: What we know, how public policy is or is not aligned with the evidence base, and what we need to know. Psychological Science in the Public Interest, 10, 49-88.

Regnerus M. 2000. Shaping schooling success: Religious socialization and educational outcomes in metropolitan schools. Journal for the Scientific Study of Religion. 2000;39:363-370.

Rest, J. 1986. Moral development: Advances in research and theory. New York: Praeger.
Rose, K. K., \& Elicker, J. 2008. Parental decision making about child care. Journal of Family Issues, 29(9), 11611184.

Sekaran, U., \& Bougie, R. 2013. Research methods for business - A skill building approach, $6^{\text {th }}$ edition. West Sussex, United Kingdom: John Wiley \& Sons. ISBN: 978-1-11994225-2.

Schiffman, Leon G \& Kanuk, Leslie L., 1997. Consumer Behavior (Sixth Edition). New Jersey: Prentice Hall.

Sealey, J. 1985. Religious education: Philosophical perspectives. Boston: George Allen University.

Stolz, Jörg. 2008. Explaining religiosity: towards a unified theoretical model. The British Journal of Sociology, 2009 Volume 60 Issue 2.

Sweeney, J.C,. 2001 Consumer perceived value: The development of a multiple item scale. Journal of Retailing, Volume 77, Issue 2, Summer 2001, Pages 203220.

Sylva, K., Melhuishi, E., Sammons, P., Siraj-Blatchford, I., Taggart, B. and Elliot, K. 2003. The Effective Provision of Pre-School Education (EPPE) Project: Findings from the Pre-school Period.Available.

Walker, L. J. 2003 Morality, religion, spirituality - the value of sa- 
intliness. Journal of Moral

Education, 32(4), 373-384.

Wilkie, W. (1986). Consumer behavior. New York: John Wiley $\&$ Sons, Inc.

Wilkins, S., Shams, F. and Huisman, J. 2013. The decision making and changing behavioural dynamics of potential higher education students: The impacts of increasing tuition fees in England. Educational Studies, 39 (2). pp. 125-141. ISSN 0305-5698.

Zhang, L. 2011. Mothers' Educational Expectations and Children's Enrollment: Evidence fom Rural China. Gansu Survey of Children and Families. 